\title{
METAPHOR AND GRAMMAR IN THE POETIC REPRESENTATION OF NATURE
}

\author{
Andrew Goatly \\ Lingnan University \\ 8 Castle Peak Road, Tuen Mun, Hong Kong
}

\begin{abstract}
This article is based on two assumptions which have already been evidenced in the literature of environmental discourse analysis. The first is that the normal congruent active material process clause (Halliday and Matthiessen 2004), if the empathy hierarchy (Langacker 1991) is imposed upon it, tends to represent humans as acting in a unidirectional way upon a passive environment (Goatly 2002, 2007). The second is that much pro-environmental discourse, such as the Worldwatch Institute's reports, for the most part adopts this grammar and thereby undervalues the power of nature as a force independent of humans but with power over them (Goatly and Hiradhar 2016). This article builds on work already done in Goatly $(2000,2007)$ and Goatly and Hiradhar (2016) on non-congruent grammar, co-ordination, along with personification and other forms of metaphor, to represent the human-nature relationship in ways which are more in keeping with modern science, and more helpful from an ecological viewpoint. The poetic texts discussed are taken from Wordsworth's The Prelude, Edward Thomas' Collected Poems and Alice Oswald's Woods etc. Besides the use of grammatical co-ordination and metaphor/literalisation to blur the human nature boundary, they illustrate the use of nominalisations, ergative verbs, the activation of tokens and existents, the emphasis on nature as sayer and experiencer, rather than goal, which is a grammar (and use of metaphor) quite different from the patterns in so-called environmental and news discourse.
\end{abstract}

Keywords: environmental discourse analysis, metaphor, personification, poetic texts

\section{THE NEED FOR AN ECOLOGICAL CRITICAL DISCOURSE ANALYSIS}

The Intergovernmental Panel on Climate Change recently warned us:

Human influence on the climate system is clear, and recent anthropogenic emissions of greenhouse gases are the highest in history. Recent climate changes have had widespread impacts on human and natural systems. Warming of the climate system is unequivocal, and since the 1950s, many of the observed changes are unprecedented over decades to millennia. The atmosphere and ocean have warmed, the amounts of snow and ice have diminished, and sea level has risen. Each of the last three decades has been successively warmer at the Earth's surface than any preceding decade since 1850. The period from 1983 to 2012 was likely the warmest 30-year period of the last 1400 years in the Northern Hemisphere, where such assessment is possible (medium confidence). (http://ipcc.ch/pdf/ assessment-report/ar5/syr/AR5_SYR_FINAL_SPM.pdf retrieve 28/7/2015)

The consequences of global warming could be disastrous: extreme weather, causing droughts, heatwaves and floods, and the resulting loss of life, infrastructure and agriculture. Melting permafrost would release methane (a far more dangerous greenhouse gas than $\mathrm{CO}_{2}$ ), multiplying these threats. 
In these circumstances pro-ecological Critical Discourse Analysis (CDA) should be prioritised over anti-capitalist, anti-sexist, anti-imperialist, and anti-racist CDA. As a contribution to ecological CDA this paper asks how vocabulary and grammar represent ecology/the environment and the ways humans relate to it. It demonstrates that so-called environmental texts reinforce an unhelpful representation, emphasising human power over nature, and treating nature as natural capital. However, its main purpose is to demonstrate that poems by Wordsworth, Edward Thomas and Alice Oswald represent nature in alternative ways, more conducive to ecological and human survival.

\section{FOUNDATIONS OF THE STUDY: SUMMARY OF SOME WORK ON VOCABULARY AND GRAMMAR IN ECOLOGICAL CDA}

This section summarises work on the mismatch between standard lexico-grammatical representations and modern scientific theory, and possibilities of using metaphor and grammatical modifications to improve this representation (Goatly 2007). It begins with metaphorical vocabulary and then turns to grammar.

\subsection{Metaphorical vocabulary in ecological CDA}

The importance and problem of metaphor for ecological CDA is evident in the word environment itself. In its meaning "surroundings" it instantiates the metaphor IMPORTANT IS CENTRAL, suggesting that humans are central and thus more important than nature. More positively, metaphor can be used to blur the human-nature boundary by exploiting the metaphor themes LANDSCAPE IS HUMAN BODY and HUMAN BODY IS EARTH in the lexicon of English.

It is quite common to personify natural landscapes. Firstly, we can use parts of the human body as metaphors, e.g. face "front slope of a hill or mountain", mouth either "estuary" or "entrance to a cave", backbone/spine "central row of hills or mountains". Secondly, actions performed on the landscape can metaphorically be actions on a human body, often violent, not environmentally-friendly: gash "deep trench", rape "environmental destruction". Thirdly, verbs and adjectives normally used for humans can describe landscape: bald/bare can mean "without vegetation", virgin "unused, uncultivated". One of the advantages of such personification is that it portrays environmental destruction in terms of morality (for example, rape of the countryside) (Harvey 1996: 389).

The converse is dis-personification. Types of soil or rock can be applied to humans, often evaluatively, as nouns or adjectives: grit "bravery", clod "stupid person", flinty "severe and hostile", craggy "strong rough and attractive". Landscape gives metaphors for the human body and its parts: contour "shape of the body", tract "connected tubes in the body" or furrow "lines or wrinkles in the forehead". Physiological processes may be associated with earthquakes and volcanoes: eruption "pimple or spot, such as acne, that suddenly appears on the skin", tremor "nervous shaking of the body". Adjectives can indicate physical state, physique or character: parched "extremely thirsty", rugged "rough and strong".

Both these metaphor themes blur the human-nature boundary, and problematize the distinction fundamental to our categorisation processes. Metaphor is, indeed, a means of undoing the naturalised categories imposed by the languages we speak (Goatly 2011). 
Metaphor is also involved in another technique for blurring the human-nature distinction, the use of a word metaphorically and literally in the same text, what has been called 'literalisation' (Goatly 2011) or 'situational triggering' (Semino 2008). For example in Macbeth Duncan first uses guest metaphorically of a bird, a house martin, and then literally of himself:

The guest of summer

The temple-haunting martlet

We are your guest tonight. (Macbeth Act 1, Scene 6, 3-24)

Table 1

Transitivity and Processes in Hallidayan Grammar

\begin{tabular}{|c|c|c|c|}
\hline PROCESS & MEANINGS & PARTICIPANTS & EXAMPLE \\
\hline Existential & existence & Existent & There are 6 moons of Uranus (Ext) \\
\hline Relational & $\begin{array}{l}\text { states, } \\
\text { relationships }\end{array}$ & $\begin{array}{l}\text { Token, Value } \\
\text { Carrier/Attribute }\end{array}$ & Peter $(\mathrm{T} / \mathrm{C})$ remained a teacher $(\mathrm{V} / \mathrm{A})$ \\
\hline Material & actions, events & $\begin{array}{l}\text { Actor, Affected, } \\
\text { Recipient }\end{array}$ & $\begin{array}{l}\text { Snow (Act) blocked the road (Aff) } \\
\underline{\text { Jane }} \text { (Act) gave me (Rec) a waffle (Aff) }\end{array}$ \\
\hline Mental & $\begin{array}{l}\text { perception } \\
\text { emotion } \\
\text { thought }\end{array}$ & $\begin{array}{l}\text { Experiencer, } \\
\text { Experience }\end{array}$ & $\begin{array}{l}\text { The cat (Ex...cer) saw the bird (Exper...ce) } \\
\text { Mat (Ex...cer) hated dogs (Ex...ce) } \\
\underline{\text { He }(E x . . . c e r) ~ d e c i d e d ~ t o ~ g o ~ h o m e ~(E x . . . c e) ~}\end{array}$ \\
\hline Verbal & $\begin{array}{l}\text { speaking, writing } \\
\text { communicating }\end{array}$ & $\begin{array}{l}\text { Sayer, Receiver, } \\
\text { Verbiage }\end{array}$ & $\begin{array}{l}\text { Paul }(S) \text { told Mindy }(R) \text { he would go home }(V) \\
\text { Deirdre }(S) \text { whistled }\end{array}$ \\
\hline
\end{tabular}

In this table, and henceforth, participant-referring phrases will be underlined and process-referring bolded.

\subsection{Modern science and the need for grammatical modification}

The English language in its most simple material process grammar represents the world in ways reflecting a worldview based on Newtonian physics, rather than on modern scientific/ecological theory. (For analytical purposes henceforth I shall be using Hallidayan, Systemic Functional Grammar; see Table 1 for the relevant terminology.)

Newtonian dynamics concerned itself with the laws of motion (Prigogine and Stengers 1985: 62). By concentrating on changes involving movement (rather than chemical or evolutionary changes), Newton represented objects as basically passive or inert until acted upon by external force. This representation transferred to our dealings with nature, and, operationalised during the Industrial Revolution, caused many of our current ecological problems. Human external Actors apply force to an apparently inert nature, separate from us.

Three aspects of $20^{\text {th }}$ century science challenged the Newtonian worldview. Firstly, relativity theory undermined the belief in the existence of permanent things:

Indeed it is not possible in relativity to obtain a consistent definition of an extended rigid body, because this would imply signals faster than light... Rather... [this has] to be expressed in terms of events and processes (Bohm 1980: 123-124). 
Secondly, the second law of thermodynamics and the theory of entropy challenged the idea that natural objects can be completely controlled: it is impossible to make an engine which continuously transforms heat into an equivalent amount of mechanical work. So the energy in the universe is spontaneously being lost, or dissipated.

Thus the "negative" property of dissipation shows that, unlike [Newtonian] dynamic objects, thermodynamic objects can only be partially controlled. Occasionally they "break loose" into spontaneous change (Prigogine and Stengers 1985: 120).

A modern ecological theory, such as James Lovelock's Gaia hypothesis (Lovelock 1988), recently endorsed by geophysicists (Goatly 2007), both supports these challenges to the Newtonian worldview and represents a third. Lovelock believes the earth, Gaia including the atmosphere, the oceans, living things, the rocks and minerals of the crust functions as one large organism. The living sub-systems of the Gaia system actively and continuously work to keep the environment suitable for life. Gaia theory implies the first challenge to Newton since Gaia is a set of interacting processes. And it obviously reinforces the second challenge, because the earth goddess Gaia is not passive, but constantly organizes and regulates herself.

Table 2

Grammar, expressions and meanings in the clause

\begin{tabular}{|l|l|l|l|l|l|}
\hline \multicolumn{1}{|c|}{ Traditionally } & \multicolumn{1}{|c|}{ fishermen } & \multicolumn{1}{|c|}{ caught } & $\begin{array}{l}100,000 \text { tons } \\
\text { of fish }\end{array}$ & \multicolumn{1}{|c|}{ a year } & \multicolumn{1}{|c|}{$\begin{array}{c}\text { in the North } \\
\text { Sea }\end{array}$} \\
\hline $\begin{array}{l}\text { Circumstance } \\
\text { (temporal) }\end{array}$ & $\begin{array}{l}\text { Participant } \\
\text { (Actor) }\end{array}$ & $\begin{array}{l}\text { Process } \\
\text { (Material) }\end{array}$ & $\begin{array}{l}\text { Participant } \\
\text { (Affected) }\end{array}$ & $\begin{array}{l}\text { Circumstance } \\
\text { (temporal) }\end{array}$ & $\begin{array}{l}\text { Circumstance } \\
\text { (locational) }\end{array}$ \\
\hline Adverbial & $\begin{array}{l}\text { Nominal } \\
\text { Subject }\end{array}$ & Finite Verb & $\begin{array}{l}\text { Nominal } \\
\text { Object }\end{array}$ & Adverbial & Adverbial \\
\hline
\end{tabular}

Moreover, Gaia theory makes a third challenge: human and other systems of the biosphere are interdependent, and not separate, so exploiting nature as a resource becomes an obvious threat to the well-being of the human race as part of it.

Our problem is that English grammar (and any Standard Average European language) typically structures reality according to a Newtonian worldview. Consider the ordinary sentence 'Fisherman traditionally caught 100,000 tons of fish per year in the North Sea', analysed in Table 2. This encourages us to think in ways which are Newtonian in essence, but according to modern science, misguided in three ways.

1. The division into nouns, referring to permanent things - fisherman, fish, the North Sea - and verbs, referring to processes - catching. It would be more scientific to think of fish, fisherman, catching, and the North Sea as four interacting processes.

2. The division into the Actors who apply force or energy, the fishermen, and the inert or passive Affected, the fish. Representing the fish as inactive ignores feedback within the Gaia mechanism, as though cause and effect only operate in one direction. Actually, the fish and their commercial value cause the fishermen to catch them.

Note, also, that the subject participant (the fishermen) performs the action volitionally, while the object participant (fish) is non-volitional. The choice of subject par- 
ticipant is partly determined by the empathy hierarchy (Langacker 1991) — the following kinds of entity take the role of subject participant with decreasing likelihood:

speaker $>$ hearer $>$ human $>$ animal $>$ physical object $>$ abstract entity

This hierarchy accounts for the following data:

The dog chased me. I was chased by the dog.

I chased the dog. ?? The dog was chased by me.

This last clause is unlikely because the subject referent, the dog, is lower in the empathy hierarchy than the speaker.

Speakers, hearers, humans, and animals, the probable subject agents, are capable of volition, whereas, commonsensically, physical objects and abstract entities are not. This increases the likelihood that subject referents (Actors) will be exercising volition.

Consequently, the empathy hierarchy reinforces the following prototypical representation of a material process clause: a human volitional Actor acts upon a passive (perhaps non-human) Affected.

3. This sentence marginalises the 'environment' or location circumstance, suggesting the North Sea is either powerless, or is not affected. However, catching so many tons of fish obviously changes the North Sea's ecosystem. This too denies the interrelatedness stressed by Gaia theory.

We need a grammar which constructs a worldview which better reflects modern scientific/ecological theory, and I have suggested elsewhere (Goatly 2007: 306-315) structures and grammatical resources which could be used in this way. These include the following:

Location Circumstance as Actor.

Instead of marginalising the environment by referring to it in a location circumstance, we have the option of turning it into a subject, or Actor.

Ants are crawling all over the bed $\rightarrow$ The bed is crawling with ants.

The environment, the bed, becomes a participant in the process, not separate or in the background.

Ergativity

An increasing number of verbs belong to the ergative paradigm (Halliday 1994: 163 172), for example, sail, tear and cook (see Table 3).

Table 3

Ergative clause patterns

\begin{tabular}{|l|l|l|l|l|l|}
\hline \multicolumn{2}{|c|}{ Intransitive/Middle } & & \multicolumn{3}{c|}{ Transitive/Effective } \\
\hline \multicolumn{1}{|c|}{ MEDIUM } & PROCESS & & \multicolumn{1}{c|}{ INSTIGATOR } & PROCESS & \multicolumn{1}{c|}{ MEDIUM } \\
\hline The boat & sailed & v. & Mary & sailed & the boat \\
\hline The cloth & tore & v. & The nail & tore & the cloth \\
\hline The rice & cooked & v. & Pat & cooked & the rice \\
\hline
\end{tabular}

The difference between ergative and non-ergative verbs is that when two participants are involved, i.e. Actor + Affected or Instigator + Medium, in transitive/effec- 
tive clauses, the clause extends in a different directions: with non-ergatives to the right, with ergatives to the left. Compare John ate/John ate the grape with the ergative the climate changed/humans changed the climate.

Middle ergative verbs, without an object, represent changes to a participant, the Medium, as self-generated. For example, 'the door opened' suggests the energy for this process originated in the door. This reflects the second thermodynamic challenge to Newton. 'Occasionally [objects] "break loose" into spontaneous change' (Prigogine and Stengers 1985: 120). Incidentally, in Australian aboriginal languages ergative middles also reinforce the identity between people and things (Muhlhäusler 1996: 123).

\section{Nominalisation}

Nominalisation represents processes as nouns. By blurring the process/thing distinction, nominalisation can suggest that things are in fact processes, reflecting the first scientific challenge to Newton. Moreover, nominalisations often exclude reference to agents or external causes, suggesting, like middle ergatives, a self-generated process.

However, in ecological discourse, ergativity and nominalisation are double-edged. By obscuring human agency they may avoid telling us who is responsible for destroying the environment (Schleppegrell 1996).

\section{Animation or Personification}

Besides using metaphorical vocabulary in the dictionary of English which blurs the distinction between humans and the landscape, grammar modification can represent nature as less than inert, as animate.

First, we can metaphorically reconstruct Experiences in mental process clauses as though they were Actors in material processes, termed 'activation of Experiences'. For instance, I noticed the river $\rightarrow$ the river arrested my gaze.

Second, we can metaphorically reconstruct relational and existential processes into material ones, termed 'activation of Tokens /Existents', making nature active rather than static. For example: There are five trees in the valley/five trees are in the valley $\rightarrow$ Five trees stand in the valley.

Besides these specific activations, there are general patterns of animation and personification: natural things, traditionally considered inanimate and non-volitional, may become subjects of verbs normally used for living things (animation) or humans (personification), e.g. the echoes died, the wind complained.

\section{Co-ordination}

Besides these grammatical 'metaphors' the use of co-ordination can suggest that the human and non-human belong to the same category. For instance in the lines from Edward Thomas

\section{And $I$ and star and wind and deer}

Are in the dark together

the human, astronomical, meteorological and animal are not only listed together but are joint subjects of the predicate 'are in the dark together'. 
Natural participants in clauses

\begin{tabular}{|c|c|c|c|}
\hline Participant & Examples & Number & $\%$ \\
\hline Affected & $\begin{array}{l}\text { programs that improve the environment; metals are recycled; } \\
\text { values that protected animals and habitats }\end{array}$ & 127 & 48 \\
\hline Actor transitive & $\begin{array}{l}\text { the forest now provides the village with food; different species of } \\
\text { coral build structures of various sizes }\end{array}$ & 36 & 13.5 \\
\hline Token-Carrier & $\begin{array}{l}\text { water is becoming scarce; they [rabbits] are also responsible } \\
\text { for serious erosion problems; }\end{array}$ & 32 & 12 \\
\hline Medium middle & $\begin{array}{l}\text { phytoplankton have increased; their [corals'] shell or skeleton } \\
\text { may even start to dissolve; }\end{array}$ & 14 & 5.5 \\
\hline Experience & $\begin{array}{l}\text { why worry about a few thousand rare species } \\
\text { ever heard about?; enjoy exciting and diverse nature; }\end{array}$ & 13 & 5 \\
\hline $\begin{array}{l}\text { Actor } \\
\text { intransitive }\end{array}$ & $\begin{array}{l}\text { a tree falls in the forest; } \underline{\text { a long-suffering waterway that flows }} \\
\text { through the nation's capital; }\end{array}$ & 12 & 4.5 \\
\hline $\begin{array}{l}\text { Medium } \\
\text { effective }\end{array}$ & $\begin{array}{l}40 \% \text { of vegetables... were grown in home and community gar- } \\
\text { dens; composting ...builds up soil nutrients; }\end{array}$ & 5 & 2 \\
\hline Other & & 28 & 10.5 \\
\hline
\end{tabular}

Natural participants in nominalisations

\begin{tabular}{|l|l|c|c|}
\hline \multicolumn{1}{|c|}{ Participants } & \multicolumn{1}{|c|}{ Examples } & Number & $\%$ \\
\hline Affected & $\begin{array}{l}\text { the degradation of our shared environment; forest manage- } \\
\text { ment; control of our atmosphere, land, forests, mountains and } \\
\text { waterways; }\end{array}$ & 167 & 78.5 \\
\hline Medium & climate stabilization; oil spill; soil erosion; & 9 & 4 \\
\hline $\begin{array}{l}\text { Actor } \\
\text { intransitive }\end{array}$ & flows of minerals; saltwater intrusion; land subsidence; & 8 & 4 \\
\hline Experience & $\begin{array}{l}\text { attention to the environment; knowledge and information } \\
\text { about weather; }\end{array}$ & 7 & 3 \\
\hline Actor transitive & $\underline{\text { climate shocks; drought strikes; impacts of GM soy; }}$ & 5 & 2.5 \\
\hline Other & & 17 & 8 \\
\hline
\end{tabular}

\section{ANTHROPOCENTRISM AND THE GRAMMAR OF ENVIRONMENTAL DISCOURSE IN THE STATE OF THE WORLD 2012}

Against this theoretical backdrop of an anti-ecological Newtonian grammar and alternative pro-ecological grammatical structures I analysed an 'environmental' scientific text, the 2012 Worldwatch Institute report, The State of the World 2012 (SOTW).

I identified all nouns referring to natural phenomena that were participants in clauses. And also nouns in nominalisations, whenever their participant roles in the equivalent de-nominalised clause could be discerned. These were then classified according to the Hallidayan scheme of transitivity (See Table 1) including the ergative option (Table 3) (Halliday and Matthiessen 2004). The main finding was that the grammati- 
cal choices continue to reflect the dominant Newtonian paradigm of humans acting on a passive nature.

Tables 4 and 5 indicate that nature is predominantly an Affected, both in clauses, $48 \%$, and even more in nominalisations, 78.5\%. Natural elements as Transitive Actors and Tokens-Carriers have some significance in clauses, but natural elements in the other categories are negligible.

The most common nominalised phrases are climate change (59 times), land use (23 times) and air pollution (10 times). With land use the unstated Actors are obviously humans, and an external Actor or agent is responsible for air pollution. However, climate change nominalises an ergative verb, which makes the Medium more powerful, and, problematically, might also excuse those changing the climate, the Instigators, from some of the responsibility.

\subsection{Most important processes by which nature is affected}

The figures in Tables 4 and 5 show that verbs and their nominalisations assume a (human) power over nature. In places the report even presumes that humans create natural products:

meat, egg and dairy production; chicken production; farmers who previously produced small quantities of low-quality honey; etc. etc.

Apparently bees, chickens and cows contribute little to this process!

Patterns of interaction with the environment also stress human power over nature. Firstly the environment, especially land and water, is used by humans:

land use (23 times); water usage ( 3 times); water use (3 times); the use of mangrove areas; cereals that were used for animal feed; etc.

Use is very often a matter of consumption: meat consumption (2 times); fish consumption per person; water consumption, etc.

This consumption usually refers to eating and feeding:

corn and soyabean are fed to animals, animals are fed to us; cereals that were used for animal feed; people in industrial regions still eat much more meat; etc.

Another kind of human domination of the environment is the extraction of minerals: to extract precious metals; the extraction of oil, gas and coal, etc.

Human use of the environment often leads to excessive exploitation:

exploit the turtle population; commercial fish stocks are fully exploited; severe overexploitation of sturgeon; etc.

The effects of this human use, consumption, and exploitation are negative on ecology. Degradation:

land degradation (3 times); ecosystem degradation (2 times); human induced soil degradation; etc.

Or pollution:

air pollution (10 times); pollute the air, atmosphere, soil or water, etc. 
Or more severely, destruction;

habitat destruction (2 times); the destruction of planet earth; companies that were destroying Indonesian rainforests; etc.

SOTW envisages the solutions to environmental problems as more human action on the environment. It needs to be managed:

water management (3 times); river basin management; forest management; etc.

Negative effects need to be prevented by preserving or saving it:

preserving all life in all its forms; preserving an ecosystem and its services intact. etc.

save the planet; saving coral reefs; etc.

Or reversed by restoration:

restoring ecosystems like forests and wetlands; restore Earth's systems;

the restoration of public and marginal lands; etc.

To sum up: humans act on a passive nature, by using and exploiting it and therefore degrading, polluting and even destroying it, and the solution is more human intervention and action on a relatively powerless nature.

\subsection{The representation of active nature}

However, though mainly represented as powerless Affecteds, in $13.5 \%$ of clauses natural elements are powerful transitive Actors (Table 4). These clauses mostly represent nature as providing and supplying goods/services to sustain and support human populations:

\section{Provide}

the ecological systems that provide us with fresh water, soil, clean air, a stable climate .... pollination and dozens of other ecosystem services; ecosystems provide essential services; the services that ecosystems provide to humans; etc.

\section{Sustain, support, supply}

the ability of the planet's ecosystems to sustain future generations; ecosystems support human well-being; the 60 billion livestock animals that now supply the world's meat, eggs and dairy products; etc.

Indeed nature is often represented in terms of economic units such as assets, money or capital:

earth's natural capital (3 times); natural assets; common assets, and eco-system services; the world's common biological wealth; environmental bankruptcy; etc.

Note, too, under the heading provide, the repeated word services. The suggestion is that, in accordance with neo-liberalism, the way to save the planet's ecology is to make it marketable as an asset valued in monetary terms. (For arguments against this 'natural capital agenda' see Monbiot 2014 and Harvey 1996: 152 - 155).

To sum up. Analysis of these grammatical patterns and the most commonly used verbs in clauses and nominalisations shows clearly SOTW's depiction of nature is predominantly anthropocentric. Nature is used by humans, and if over-/mis-used the resulting environmental destruction is important simply because it threatens nature's ability to provide humans with necessary resources and services. 


\section{NATURE POETRY}

As a contrast, let's turn to poetry and its grammatical representation of natural elements. Firstly we can quantitatively compare SOTW with the Collected Poems of Edward Thomas and Wordsworth's The Prelude.

\subsection{Sayers and actors in state of the world contrasted with Edward Thomas and Wordsworth}

In Edward Thomas 31.5\% of natural element participants in clauses are Actors/Sayers; in SOTW the total is $23.5 \%$ including Mediums. Of these there are no Sayers and more than half, $13.5 \%$, are transitive Actors, mainly those supplying or providing goods and services to humans.

Table 6

Actors and Sayers in Thomas' poems and State of the World

\begin{tabular}{|l|c|c|c|c|c|}
\hline & Experiences & Transitive Actors & $\begin{array}{c}\text { Intransitive } \\
\text { Actors }\end{array}$ & Sayers & $\begin{array}{c}\text { TOTAL } \\
\text { Actors + Sayers }\end{array}$ \\
\hline Thomas & $10.5 \%$ & $10.5 \%$ & $15 \%$ & $6 \%$ & $31.5 \%$ \\
\hline SOTW & $5 \%$ & $13.5 \%$ & $10 \%$ & $0 \%$ & $23.5 \%$ \\
\hline
\end{tabular}

\section{Actors}

In Thomas natural elements are more frequently intransitive Actors (15\%) than transitive $(10.5 \%)$, and the figures for animals and birds in Wordsworth are even more different $(9.2 \%$ intransitive, $0.7 \%$ transitive (Table 7 , column 2$)$ ). These figures give an opposite pattern to that in $\operatorname{SOTW}(10 \%$, if we include ergative middles, to $13.5 \%)$. While natural elements in SOTW 2012 have to make an impact and benefit humans to be Actors, in The Prelude natural elements' actions are worth describing, quite apart from any effect on entities beyond themselves.

The eagle soars high in the element

That lowly bed whence I had heard the wind

Roar and the rain beat hard

Landscape, as a proportion of participants, also figures quite frequently in The Prelude as an intransitive Actor or Medium (Table 7, column 4). The following passage describes the young Wordsworth ice-skating, and the the last nine lines illustrate a dynamic interaction between humans and nature, as though the skater's movement makes him aware of an energy inherent in the banks and cliffs:

So through the darkness and the cold we flew,

And not a voice was idle; with the din

Smitten, the precipices rang aloud;

The leafless trees and every icy crag

Tinkled like iron;

and oftentimes,

When we had given our bodies to the wind,

And all the shadowy banks on either side 
Came sweeping through the darkness, spinning still

The rapid line of motion, then at once

Have I reclining back upon my heels,

Stopped short; yet still the solitary cliffs

Wheeled by me even as if the earth had rolled

With visible motion her diurnal round!

Ergative verbs are prominent here: sweep, spin, wheel, ring and tinkle.

Landscape Actors in intransitive clauses give us an example of a second kind of pro-ecological grammatical modification. The examples below promote what is literally a location circumstance into an Actor (or perhaps Sayer).

... and all the pastures dance with lambs

... the broad world rang with the maiden's name

The land all swarmed with passion

My soul, .......

A rock with torrents roaring

Compare these with 'lambs dance in all the pastures', 'the maiden's name rang through the broad world', 'passion swarmed over the land', and 'torrents roared around/ over the rock'.

We have been looking at the way landscape features as Actor in intransitive clauses. However, in The Prelude landscape is an Actor 50\% more in transitive clauses than intransitive (Table 7, column 4), and it is this active nature of the landscape in Wordsworth which sets it apart from landscape as commonsensically conceived. Typically mountains feature as these transitive Actors:

I had seen ....

The western mountain touch his setting orb

A huge peak, black and huge,

As if with voluntary power instinct

Upreared its head.

And mountains over all, embracing all.

Weather is the most important transitive Actor (Table 7. column 5), but, whereas landscape seems to act on other natural objects, weather affects humans and the poet in particular. The very opening of The Prelude demonstrates:

Oh there is blessing in this gentle breeze,

A visitant that while it fans my cheek

Doth seem half-conscious of the joy it brings

In another famous passage the boy Wordsworth feels the wind (and grass and rock) supporting him as he climbs steep crags:

...... I have hung

Above the raven's nest, by knots of grass

And half-inch fissures in the slippery rock

But ill sustained, and almost (so it seemed)

Suspended by the blast that blew amain,

Shouldering the naked crag... . 
In sum, what distinguishes the Actors in The Prelude is the energy of natural elements usually regarded as lifeless - weather, water, and even landscape.

\section{Sayers}

Sayers are totally absent from SOTW 2012. In fact, the report expects the United Nations Environment Program 'to serve as the voice of the environment'.

By contrast Edward Thomas and Wordsworth see nature as a communicator. Almost two-thirds (47/72) of natural element Sayers in Thomas are birds. For instance:

This was the best of May - the small brown birds

Wisely reiterating endlessly

What no man learnt yet, in or out of school. ('Sedge Warblers')

Sayers in The Prelude are associated with both animals and birds (Table 7 column 2) where $10.7 \%$ of the natural elements, and also rivers and streams (column 3 ) $5.8 \%$. Let's look at some examples of animals and birds first:

By the still borders of the misty lake,

Repeating favourite verses with one voice,

Or conning more, as happy as the birds

That round us chaunted.

The heifer lows, uneasy at the voice

Of a new master; bleat the flocks aloud.

As for bodies of water as Sayers, Wordsworth is, by his own admission

.... a spoiled child... in daily intercourse

With those crystalline rivers, solemn heights,

And mountains, ranging like a fowl of the air.

Indeed, in Wordsworth's ideal world, human interference should not inhibit their powers of communication:

Table 7

Participant roles as a percentage of all noun phrases within natural categories in The Prelude

\begin{tabular}{|l|c|c|c|c|c|}
\hline & Animals/Birds & Water & Landscape & Weather & Plants \\
\hline Actor Trans & $0.7 \%$ & $5.8 \%$ & $4.8 \%$ & $22.6 \%$ & $5.8 \%$ \\
\hline Actor Intrans & $9.2 \%$ & $6.2 \%$ & $3.2 \%$ & $24.8 \%$ & $9.7 \%$ \\
\hline Sayer & $10.7 \%$ & $5.8 \%$ & $1.1 \%$ & $3 \%$ & $1.8 \%$ \\
\hline Experiencer & $4.6 \%$ & $1.2 \%$ & $1.4 \%$ & $0.75 \%$ & $1.1 \%$ \\
\hline Experience & $19.8 \%$ & $4.6 \%$ & $4.4 \%$ & $3.8 \%$ & $6.9 \%$ \\
\hline Affected & $19.8 \%$ & $9.3 \%$ & $16 \%$ & $16.6 \%$ & $15.5 \%$ \\
\hline
\end{tabular}

NB The percentages do not add up to 100 , because the $100 \%$ includes participants in relational and existential clauses, and non-participants, e.g. NPs in post- or pre-modifying structures or adjuncts.

The famous brook, who, soon as he was boxed

Within our garden, found himself at once,

As if by trick insidious and unkind,

Stripped of his voice ... 


\subsection{Nature as Experience rather than Affected}

Just as natural Sayers affect human consciousness so do Experiences, which are twice as frequent in Thomas as in SOTW 2012 (10.5\% compared to 5\% in Table 6). For example,

All things forget the forest

Excepting perhaps me, when now I see

The old man, the child, the goose feathers at the edge of the forest,

And hear all day long the thrush repeat his song_('The Green Roads')

And in Wordsworth we see a significant representation of nature as Experiences in birds and animals (19.8\% in Table 7 column 2$)$ and plants (6.9\% in column 6).

At leisure, then, I viewed, from day to day,

The spectacles within doors, birds and beasts

Of every nature

$$
\text { ..see that pair, the lamb }
$$

And the lamb's mother, and their tender ways

In Thomas the affective mental process responses to Experiences of nature are crucial, in, for example, these lines from 'November'.

Few care for the mixture of earth and water,

Twig, leaf, flint, thorn,

Straw, feather, all that men scorn,

Pounded up and sodden by flood,

Condemned as $\mathrm{mud}^{4}$

\section{Another loves earth and November more dearly \\ Because without them, he sees clearly, \\ The sky would be nothing more to his eye \\ Than he, in any case, is to the sky; \\ He loves even the mud whose dyes \\ Renounce all brightness to the skies.}

In this and the previous section we have shown that in Thomas and Wordsworth nature, especially birds, animals and water are more serious communicators than their counterparts in SOTW 2012 and therefore figure more as Experiences to which we pay attention. In $S O T W$, by contrast, they are never Sayers, and the ratio of Experiences to Affecteds is much lower.

Thomas and Wordsworth emphasise that nature can speak to us as a Sayer or affect us as an Experience. Being receptive to nature's messages as Experiencers gives us a direction for our scientific and technological advances different from exerting material power over an affected nature.

\subsection{Activation of Experiences, Tokens}

Upgrading Experiences to Actors is widespread and stylistically significant in The Prelude. It applies most obviously to plants, landscape and weather. In a more common- 
sense syntax the following clauses would be mental, though paraphrasing into such syntax (attempted in brackets) can be problematic:

Till the whole cave, so late a senseless mass,

Busies the eye with images and forms

Boldly assembled

(cf. I saw the whole cave...)

Oh there is blessing in this gentle breeze,

A visitant that while it fans my cheek

Doth seem half-conscious of the joy it brings

From the green fields, and from yon azure sky.

(cf. I enjoyed (the breeze fanning my cheek)

..my favourite grove,

Tossing in sunshine its dark boughs aloft,

As if to make the strong wind visible,

Wakes in me agitations like its own

(cf. I fear my favourite grove/my favourite grove worries me)

Another significant pattern in Wordsworth and Thomas is the activation of Tokens or Existents (2.2), making nature more active than static:

The garden lay

Upon a slope surmounted by a plain

Of a small bowling-green; beneath us *stood

A grove

There rose a crag,

That, from the meeting-point of two highways

Ascending, *overlooked them both

Instead of 'being at the top of' an eminence or slope or two highways, the plain or crag 'surmounts' or 'overlooks' them, and in this environment even stood seems to take on more energy. Such activations partly account for the high percentage $(16 \%)$ of landscape as Affected in the Prelude (Table 7).

Similar activations of Tokens in Thomas include:

The fields beyond that league close in together

And merge [cf. 'are together and indistinguishable']

The road, the wood that overhangs [cf. 'is above']

And *underyawns [cf. 'is below'] it

A white house *crouched ['was in a low position'] at the foot of a great tree.

Typically paths and roads are not just positioned next to a place or between two places but run, mount, or take you from one to the other:

Where the firm soaked road

*Mounts beneath pines

On all sides then, as now, paths * ran to the inn;

And now a farm-track *takes you from a gate. 


\subsection{Personification, co-ordination dissolving the human-nature distinction}

Some activations of Experiences/Tokens/Existents above have been asterisked, to indicate personification or animation, problematizing the human-nature boundary. LANDSCAPE IS HUMAN BODY, discussed earlier, is a specific sub-set of such personifications. Personification is particularly common in Thomas, whether of light:

When mist has been forgiven

And the sun has stolen out,

Peered, and resolved to shine at seven

Or plants

On the prone roof and walls the nettle reigns.

Or weather

All day the air triumphs with its two voices

Of wind and rain:

As loud as if in anger it rejoices

Sometimes the personification is used very subtly, as in 'Aspens':

Over all sorts of weather, men, and times,

Aspens must shake their leaves and men may hear

But need not listen, more than to my rhymes.

Whatever wind blows, while they and I have leaves

We cannot other than an aspen be

That ceaselessly, unreasonably grieves,

Or so men think who like a different tree.

Literalisation is quite complex in these lines. They confuse the literal with the personifying metaphor by co-ordinating the trees with the poet, 'they and I' and 'we', and using predicates that apply metaphorically to one and literally to the other: 'have leaves' (metaphorically sheets of paper) and 'cannot other than an aspen be' are both literal for aspens and metaphorical for the persona; and 'unreasonably grieves' is literal for the persona, metaphorical for aspens. Literalisation is clearly at work here.

Blurring the human and natural by co-ordination is also particularly common in Thomas. In earlier lines from 'Aspens' we have:

And trees and us - imperfect friends, we men

And trees since time began; and nevertheless

Between us still we breed a mystery.

'Breed' suggests they belong to the same species. Or, another example:

...... kind as it can be, this world being made so,

To stones and men and beasts and birds and flies,

To all things

\subsection{Summary}

We can now summarise the findings of section 4 . In terms of a comparison between SOTW and Thomas/Wordsworth:

- Nature is more frequently an Actor/Sayer than an Affected in Thomas / Wordsworth than in SOTW. 
- In Thomas and Wordsworth there a large number of natural Sayers, whereas there are none in SOTW.

- Among the natural Actors Thomas and Wordsworth have a higher ratio of intransitive to transitive, and SOTW the reverse, though landscape and weather are important transitive Actors in Wordsworth.

- Nature as Experience is much more common in Thomas and Wordsworth than in SOTW.

In addition, we noted the following pro-ecological techniques in Wordsworth and Thomas:

- Frequent use of the ergative middle in Wordsworth.

- Widespread activation of Experiences, Tokens and Existents.

- Personification (literalisation) and co-ordination to blur the human-nature divide.

\section{ANALYSING INDIVIDUAL POEMS BY EDWARD THOMAS AND ALICE OSWALD}

The poet Shelley claimed 'poets are the unacknowledged legislators of the world'. We can best appreciate the ways in which poetry uses language to legislate an alternative representation of nature by looking at whole poems.

July by Edward Thomas

\begin{tabular}{|ll}
$\begin{array}{l}\text { Naught moves but clouds, and in the glassy lake } \\
\text { Their doubles and the shadow of my boat. }\end{array}$ & $\begin{array}{l}\text { 1. Intransitive Actors - Er- } \\
\text { gative Middle }\end{array}$ \\
$\begin{array}{ll}\text { The boat itself stirs only when I break } & \text { 2. Nominalisation of nature as } \\
\text { This drowse of heat and solitude afloat } & \text { Transitive Actor } \\
\text { To prove if what I see be bird or mote, } & \text { 3. Experience } \\
\text { Or learn if yet the shore woods be awake. } & \text { 4. Experience } \\
\text { Long hours since dawn grew, - spread, - and } & \text { 5. Personification } \\
\text { passed on high } & \text { 6. Activation of Existents } \\
\text { And deep below, - I have watched the cool reeds hung } & \text { 7. Experience } \\
\text { Over images more cool in imaged sky: } & \text { 8. Experience } \\
\text { Nothing there was worth thinking of so long; } & \text { 9. Sayer } \\
\text { All that the ring-doves say, far leaves among, } & \text { 10. Verbiage of birds as Transi- } \\
\text { Brims my mind with content thus still to lie. } & \text { tive Actor / Instigator - } \\
& \text { 1. Derb made Ergative }\end{array}$ \\
& 12. Literalisation \\
\hline
\end{tabular}

Some of these observations are obvious - the ergative middle (1), the common occurrence of nature as Experience $(3,7,8)$ and the personification (5). But 2, 'the drowse of heat' is interesting as one likely interpretation would make 'heat' an Actor/Instigator and 'drowse' a nominalisation of the verb to drowse. This verb is normally simply intransitive, but this interpretation would make the equivalent un-nominalised clause ergative effective - 'the heat/solitude causes me to drowse'. Similarly, the verb brim (10), normally simply intransitive, is turned into an ergative effective verb. Compare the more 
normal grammar of 'My mind brims with all that the ring doves say.' Moreover applying brim, a verb literally used of water to the mind (11) (12), blurs the distinction between human persona and the literally brimming lake on which he is floating, a literalisation or situational trigger in Semino's terms. As for (6), the verbs 'grew' 'spread' and 'passed' are a kind of activation of Existents, equivalent to 'came into existence', 'established its existence' and 'ceased to exist', respectively (see also note (2) in the next poem).

The Mill-water by Edward Thomas

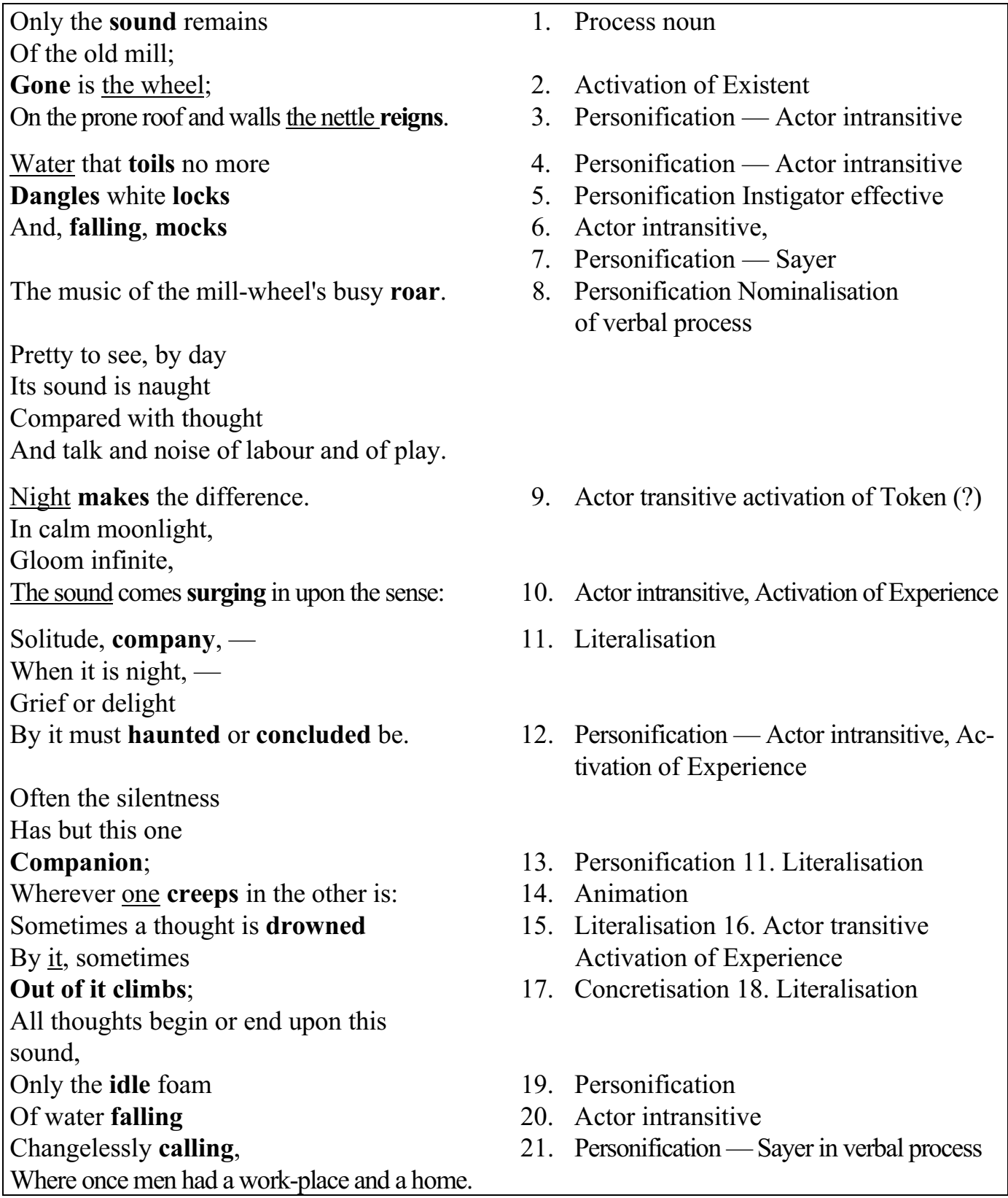


Nettles (3), night (9), and, more often, water (4) (5) (7) (21), its foam (19), and the sound of water/mill wheel (8) (12) (13) (14) are personified (animated) in quite straightforward ways. They are usually represented as human Actors, or as sayers (7) (21). As Actors they are transitive/effective (5) (9) (16), or more often intransitive (3) (4) (6) (10) (12) (20), reflecting patterns we observed in the previous quantitative analysis of Wordsworth and Thomas. But less simply, we might consider that when the sound of water is a (personified) actor (10) (12) (16), this is equivalent to the activation of experiences - the sound impinges on the consciousness of an experiencer, 'surges in upon the sense' (10). Sound is a process noun (1), like a nominalisation, and as a noun it can be recoded as an Actor. Night is activated too, changing from token/circumstance to actor-compare 'Night is different'/'It is different at night' with 'Night makes a difference' (9).

The poem also illustrates interesting uses of literalisation or situational triggering. The sound of the water is metaphorically a companion (11) echoing the literal company which it haunts or ends (concludes), thereby blurring the human-water boundary. In a similar blurring the water, which can literally drown, metaphorically drowns human thought (15), suggesting it materially affects the mental process of cognition. And the thought in the brain can metaphorically climb out of this (sound of) water, literal in context (18). By these literalisation techniques, humans and human thought processes are confused with water and the sound of water.

Sonnet by Alice Oswald

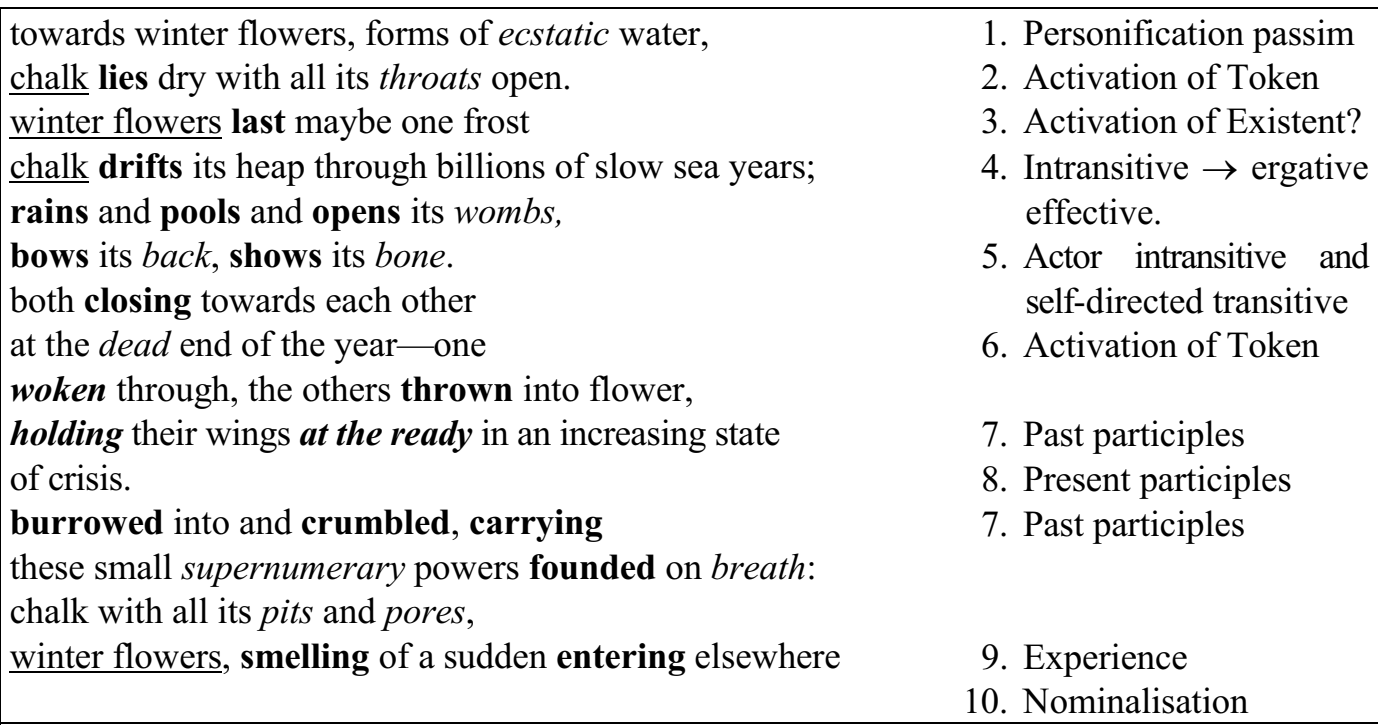

Most obviously this poem exploits of the metaphor theme LANDSCAPE/EARTH IS HUMAN BODY. All the italicised vocabulary personifies the chalk in this way (1). 'Pits', a conventional metaphor for small depressions in the skin, reverses the metaphor. Even 'supernumerary' personifies, as it usually refers to a temporary employee or extra member of a social group. The chalk/body is often sexualised. So 'breath' is ambiguous. It could be the heavy breathing of the chalk through its open throats waiting for the pene- 
tration by flowers. Or the carbon dioxide which forms the basis of the calcium carbonate of the chalk, and which the flowers take in and photosynthesise into oxygen.

Turning to the grammar of processes, in the context of so much sexualised personification 'lies' (2) activates 'chalk' from a Token into an intransitive Actor, as though lying on a bed. 'Last' (3) might be seen as an activation of an Existent - "continues to exist". Straightforwardly we note chalk as an intransitive Actor of the verbs 'rains' and 'pools' (5). When it is a transitive Actor subject of 'opens', 'bows', 'shows' and 'drifts' $(5,4)$ chalk is not acting on anything beyond itself, rather like the intransitive Actors noted in Wordsworth's representation of animals and birds. 'Drifts' (4), like 'brims' in 'July', exemplifies the conversion of an intransitive verb into an ergative effective verb. As we perceive the chalk's shapes and formations it is static. But from the perspective of billions of years of geological processes these verbs make us see the shapes of the chalk as active - a radical activation of nature. A more familiar kind of Token activation is 'closing' (6) equivalent to 'the flowers and the chalk are close to each other'.

In (7) the Actors of the past participles 'woken', 'thrown', 'burrowed', 'crumbled', 'founded' may be inferred from the context in most cases - it is probably the flowers that have woken, burrowed and crumbled the chalk. But who threw the flowers and founded the chalk is less certain. This resembles a pattern common in Thomas: frequent use of passives and past participles suggests a (divine?) force behind the natural world (Goatly in press). Although the present participles 'holding' and 'carrying' (8) are transitive verbs with presumably the flowers and chalk as Actors, the flowers' action of holding their wings only affects themselves. In (9) winter flowers are an Experience of the process 'smelling' (9). However, could the flowers also be an Experiencer sensing a sudden entering or penetration elsewhere? Anyway, the nominalisation creates ambiguity as to the Actor/Affected-water entering the chalk, or flowers the chalk? Paradoxically it seems to be the flowers, traditionally seen as female, that are more like males entering the throat or womb of the chalk. The fact that we cannot easily identify the specific Actor, perhaps hints at the primacy of process, as in quantum mechanics.

\section{Birdsong for Two Voices by Alice Oswald}

a spiral ascending the morning,

climbing by means of a song into the sun,

to be sung reciprocally by two birds at intervals 1 . Sayer

in the same tree but not quite in time.

a song that assembles the earth

out of nine notes and silence.

out of the unformed gloom before dawn

where every tree is a problem to be solved by birdsong.

Crex Crex Corcorovado,

letting the pieces fall where they may, every dawn divides into the distinct

misgiving between alternate voices
2. Nominalisation as transitive Actor-creative process

3. Nominalisation as transitive Actor

4. Transitive Actor

5. Ergative middle

6. Nominalisation 
sung repeatedly by two birds at intervals out of nine notes and silence.

while the sun, with its fingers to the earth, as the sun proceeds so it gathers instruments:

it gathers the yard with its echoes and scaffolding sounds,

it gathers the swerving away sound of the road, it gathers the river shivering in a wet field,

it gathers the three small bones in the dark of the eardrum;

it gathers the big bass silence of clouds

and the mind whispering in its shell

and all trees, with their ears to the air,

seeking a steady state and singing it over till it settles

\section{Sayer}
8. Personification
9. Intransitive Actor
10. Transitive Actor ....
11. Nominalisations

12. Nominalisation

13. Personification

As in Thomas generally, this poem celebrates the power of birds as Sayers, birdsong. As transitive Actor birdsong 'assembles the earth' at dawn, solves the problems of the tree, and lets 'the pieces fall' $(2,3,4)$. But this powerful Actor is itself a process, a nominalisation of (birds) sing. Moreover, if you sing a song, the song does not exist independent of the process in the verb sing. The poem blends this song with the sun, phonologically, of course, 'by means of a song into the sun to be sung', and because the sun ends up 'singing' as well (18), but also because the sun too is a powerful transitive Actor or Instigator (10): it 'gathers ... instruments ... the yard ... the sound of the road ... the river ... silence of clouds ... the mind ... all trees ... bones in the ... eardrum', with this latter emphasising nature's power over humans. Notice how the human mind is co-ordinated the silence of the clouds, and all trees, suggesting an equivalence (17). It also seeks a steady state (18) — a state that does not change over time 'not quite in time', unlike the 'dawn'. The gathering is done with the sun's 'fingers' (8) personifying it, just as 'shivering' (13) personifies the river, and 'ears' (16) the trees. This latter metaphor echoes the literal 'eardrum', suggesting a deliberate literalisation, confusing humans and nature. Conversely 'shell' (15) referring to the skull or brain, by dis-personification, blurs the human-nature distinction in the opposite direction.

There are other nominalisations which emphasise process - 'scaffolding' (11) could be the actual metal bars but it only produces sounds in the process of assembly/disassembly. 'Echoes' (11) and 'swerving' (12) are clear nominalisations, and less obviously 'sound/s' refer to processes or the results of processes. The nominalisation 'misgiving' (6), rather than emphasising process, might remove an explicit Experiencer. 'Eardrum' and 'misgiving' and 'mind' hint at an Experiencer, but human presence is downplayed, and the trees with 'their ears to the air' are just as likely the Experiencers. In any case, 'misgiving' is ambiguous and might be nominalising a material process, meaning "the giving of the birdsong which is faulty because not quite in time". So the absent Experiencer is also possibly a hidden recipient. 
The only place where human consciousness is obviously present is in 'the mind whispering' (14). But this inner verbal process is comparatively weak, soft and uncommunicative compared with the all-powerful creative song of the birds and the sun.

Besides the nominalisations of the form -ing we have several present participles: 'shivering', 'whispering', 'seeking' and 'singing' suggesting ongoing and repeated processes.

This poem uses nominalisation to emphasise the process basis, the vibrations as of instruments producing sounds, reflecting the theory of quantum mechanics. Moreover, by the use of the phrase 'steady state' and the emphasis on repetition ('sung', 'singing', 'sung repeatedly') it may hint that this steady state can be achieved by the repetitive processes behind the dynamic equilibrium that Gaia theory celebrates.

Song of a Stone by Alice Oswald 1. Nominalisation/Personification

there was a woman from the north picked a stone up from the earth. when the stone began to dream it was a flower folded in

when the flower began to fruit 5 it was a circle full of light, when the light began to break it was a flood across a plain when the plain began to stretch the length scattered from the width 10 and when the width began to climb it was a lark above a cliff

the lark singing for its life was the muscle of a heart the heart flickering away 15 was an offthrow of the sea

and when the sea began to dance it was the labyrinth of a conscience when the conscience pricked the heart it was a man lost in thought 20

like milk that sours in the light, like vapour twisting in the heat, the thought was fugitive — a flare of gold -

it was an iris in a field

and when the man began to murmur 25

it was a question with no answer, when the question changed its form it was the same point driven home
2. Literalisation 3. Literalisation

4. Personification

5. Animation 6. Past participle/passive

7. De-animation 8. Literalisation?

9. Ergative verb

10. Nominalisation

11. Ergative verb

12. Nominalisation 13. Ergative 14. Concretisation

15. Nominalisation. 16. Animations

17. Verbal process/Sayer

18. Personification

19. Literalisation 20. De-animation

21. Nominalisation

22. Personification/Actor

23. Personification/Actor

19. Literalisation

24. Nominalisation

8. Literalisation?

25. Ergative 26. Nominalisation

27. Nominalisation. 28. Concretisation

29. Animation/Dis-personification?

30. Nominalisation 


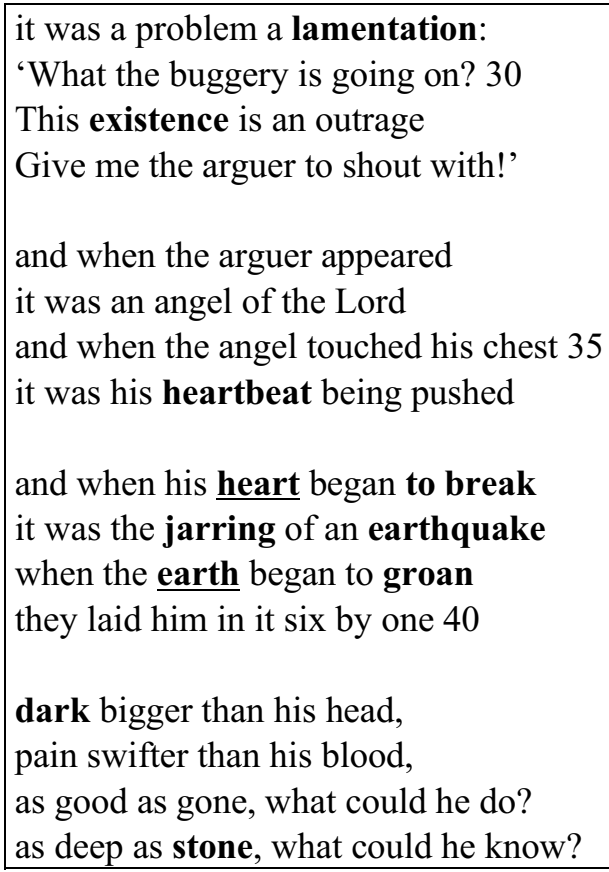

\section{Nominalisation}

32. Nominalisation
19. Literalisation 34. Ergative

35. Nominalisation 36. Dis-personification

3. Literalisation. 37. Personification/Sayer

38. Nominalisation

We can note the familiar patterns of natural elements as a Sayer in a verbal processes (1) (17), (37) Instigator in an ergative material process $(9,11,13,25,34)$, Actor in a nominalised noun phrases (22) (23) and use of passive/past participle with unstated Actor (6). But, most of the processes in this poem are relational, and, correlating with this is the compounding or layering of metaphors. The compounding makes identification of the literal and metaphorical problematic.

Stone (literal) is flower (metaphorical),

Flower (literal) is circle full of light (metaphorical)

Light (literal) is flood (metaphorical)

etc., etc.

This layering or compounding pattern makes literalisation so common that I have not noted it in these cases.

An alternative, and, perhaps, preferable interpretation of the poem is to regard it as phenomenalistic metaphor (Levin 1977). This occurs when, instead of interpreting local metaphors according to a familiar common-sense world, we imagine a (metaphorical) world in which the statements are literal. So, for example, in reading animal fables, when we read a sentence like 'the mouse spoke to the lion', we do not interpret 'spoke' as meaning "squeaked", but we imagine a world in which mice can speak to lions.

According to this interpretation, the poem describes a series of interpenetrating processes, qualities and transitory things, where neither stones, flowers, light, floods, plains, heart, sea, conscience, man, thought, flare, heartbeat, earthquake, indeed existence itself, are permanent, but shifting aspects of fleeting perception. That many of these are impermanent processes can be detected in the nominalisations of verbs: 'flood', 
'offthrow', 'thought', 'flare', 'answer', 'lamentation', 'existence', 'heartbeat', 'jarring', 'earthquake'. But we also note the nominalisations of adjectives: 'length', 'width', 'heat', and 'dark'.

These processes, qualities and things shift between the abstract, the animate (animal) the human, and the concrete/inanimate, which accounts for the concretisation (14) (28), personifications (1) (4) (18) (22) (23) (37), animations (5), (16), dis-personifications (29), (36), and de-animations (7), (20). Our commonsense categories are further jumbled, and our sense of fluctuating impermanence heightened by the literalisations extra to those arising from compounding (2), (3), (8), (19). The literalisation of earth and stone (2) (3), framing the beginning and end of the poem, suggest a circular repetition of processes. As in Gaia theory, the concrete/inanimate, the animate, and the human, merge into an interdependent unity of interconnected and re-emerging entities and processes. The poem suggests an ignorance on the part of man predicated on his transitoriness and his dependence on and involvement in these processes.

\section{SUMMARY AND POSTSCRIPT}

Though the data from just a few poems is limited, they illustrate patterns observable in the larger Thomas and Wordsworth corpus.

- Ergative verbs are used or created to construct nature (landscape) as possessing its own energy

- Experiences are activated into Actors making the experience of nature very powerful

- Nature is frequently a Sayer or Experience, communicating and affecting human consciousness

- Tokens and Existents are activated into Actors: nature does rather than is

- Nominalisations emphasise the process-basis of nature, and these processes become powerful Actors

- Passives suggest a powerful natural (or divine) force

And in addition Thomas and Oswald blur the human-nature distinction through:

- Personification, animation (and their reverse)

- Literalisation - using metaphors triggered by the literal context

- Co-ordination of the human and non-human

The view of the natural world represented by these poets, reflected in their grammar and metaphors, provides a much better model for our survival than SOTW 2012. It emphasises our inclusion within nature, nature's power to act and communicate, and our need to respond to it as Experience and recognise it as process. In this latter respect, poetry and science seem in accord with each other and to resist representing nature in a common-sense way as a passive resource. We had better take note of Wordsworth, Thomas, and Oswald, the physicists and the ecologists, if we are to avoid the dire predictions of the Inter-governmental Panel on Climate Change.

(C) Andrew Goatly, 2017 


\section{REFERENCES}

Bohm, D. (1980) Wholeness and the Implicate Order, London: Routledge.

Goatly, A. (2007) Washing the Brain: Metaphor and Hidden Ideology, Amsterdam: Benjamins.

Goatly, A. (2011) The Language of metaphors, $2^{\text {nd }}$ edition, Abingdon: Routledge.

Goatly, A. (in press) 'The poems of Edward Thomas: a case study in Ecolinguistics'.

Goatly, A. and Hiradhar, P. (2016) Critical Reading and Writing in the Digital Age, Abingdon: Routledge.

Halliday, Michael (1994) An Introduction to Functional Grammar $2^{\text {nd }}$ edition, London: Arnold.

Halliday, Michael and Matthiessen, Christian (2004) An Introduction to Functional Grammar, London: Hodder.

Harvey, D. (1996) Justice, Nature and the Geography of Difference, Cambridge Mass.: Oxford.

Langacker, R.W. (1991) Foundations of Cognitive grammar, vol. 2: Descriptive Applications, Stanford: Stanford University Press.

Levin, S.R. (1977) The Semantics of Metaphor, Baltimore: Johns Hopkins UP.

Lovelock, J. (1988) The Ages of Gaia Oxford: OUP.

Monbiot, G. (2014) 'The pricing of everything' http://www.monbiot.com/2014/07/24/the-pricingof-everything/retrieved 26/07/2014.

Muhlhäusler, P. (1996) 'Linguistic adaptation to changed environmental conditions' in Fill, A. (ed.) Sprachokologie und Okolinguistik, Tubingen: Stauffenburg Verlag.

Oswald, A. (2005) Woods etc., London: Faber and Faber.

Prigogine, Ilya and Stengers, I. (1985) Order out of Chaos, London: Flamingo.

Schleppegrell, Mary, J. (1996) 'Abstraction and agency in middle school environmental education', in J. C. Bang, J. Door, Richard J. Alexander, Alwin Fill and Frans Verhagen (eds) Language and Ecology: proceedings of the symposium on ecolinguistics of AILA '96, Jyvaskala, Odense: Odense University Press, pp. 27-42.

Semino, E. (2008) Metaphor in Discourse, Cambridge: Cambridge University Press.

State of the World 2012: creating sustainable prosperity, (2012) The Worldwatch Institute.

Thomas, E. (1949) Collected Poems, London: Faber and Faber.

Wordsworth, W. (1933/1960, first published 1805) The Prelude, Oxford University Press.

\section{Article history:}

Received: 10 September 2016

Revised: 23 September 2016

Accepted: 29 September 2016

\section{For citation:}

Goatly, Andrew (2017) Metaphor and Grammar in the Poetic Representation of Nature. Russian Journal of Linguistics, 21 (1), 48-72.

\section{Bio Note:}

Andrew Goatly, Dr, Honorary Professor in the English Department of Lingnan University in Hong Kong. Research interests: Metaphor, including Critical Metaphor Analysis, Stylistics or the Language of Literature, Critical Discourse Analysis, including Ecolinguistics, and the Language of Humour. Contact information: http://www.ln.edu.hk/eng/andrew_goatly.php; e-mail: apgoatly@gmail.com 
DOI: $10.22363 / 2312-9182-2017-21-1-48-72$

\title{
МЕТАФОРА И ГРАММАТИКА В ПОЭТИЧЕСКОМ ИЗОБРАЖЕНИИ ПРИРОДЫ
}

\author{
Эндрю Гоутли \\ Университет Линнань \\ Tхюньмунь, Гонконг, 8 Castle Peak Road
}

\begin{abstract}
Данная статья основана на двух положениях, которые уже были доказаны в литературе по анализу экологического дискурса. Первое - это то, что в активных предложениях с конгруэнтной функцией (Halliday, Matthiessen 2004), человек предстает как исполнитель однонаправленных действий, совершаемых им над пассивной природой (Goatly 2002, 2007). Второе положение заключается в том, что в большинстве случаев в экологическом дискурсе, как, например, в сообщениях Института всемирного наблюдения (Worldwatch Institute), где такая грамматика используется, недооценивается сила природы, которая не зависит от человека и способна властвовать над ним (Goatly, Hiradhar 2016). Автор опирается на уже проведенные ранее исследования (Goatly 2000, 2007, Goatly, Hiradhar 2016), в которых показано использования неконгруэнтных грамматических форм, различных видов метафор для описании отношений между человеком и природой в русле современной науки. Автором проанализирован ряд поэтических текстов, среди которых «Прелюдии» Уильяма Вордсворта, избранные стихотворения Эдварда Томаса и поэтический сборник Элис Освальд «Woods». Исследование показало, что, помимо грамматического согласования и метафор, используемых для размывания границ между человеком и природой, в них встречаются субстантивация, эргативные глаголы, очувствление символов. Подчеркивается, что природа способна говорить и чувствовать, что существенно отличается от приемов, используемых в экологическом и новостном дискурсах.
\end{abstract}

Ключевые слова: экологический дискурс, метафора, персонификация, поэтический текст

\section{История статьи:}

Дата поступления в редакцию: 10 Сентября 2016

Дата принятия к печати: 29 Сентября 2016

\section{Для цитирования:}

Goatly, Andrew. Metaphor and Grammar in the Poetic Representation of Nature // Вестник Российского университета дружбы народов. Серия: Лингвистика. 2017. Т. 21 . № 1. C. $48-72$.

\section{Сведения об авторе:}

Эндрю Гоутли, доктор филологических наук, почетный профессор факультета английского языка в Университете Линнань (Гонконг). Сфера научных интересов: теория метафоры, анализ дискурса, экологический дискурс, стилистика, литературоведение, эколингвистика, язык юмора. Контактная информация: e-mail; apgoatly@gmail.com 